\title{
The Relationship of the Degree of Hepatic Fibrosis with Hyaluronic Acid, Type 4 Collagen, and Procollagen Type 3 N-Terminal Peptide Levels in Patients with Chronic Viral Hepatitis
}

\author{
Kronik Viral Hepatitli Hastalarda Karaciğer Fibröz Derecesi ile Hyaluronik Asit, Tip 4 Kollajen ve \\ Prokollajen Tip 3 Amino-Terminal Peptid Düzeyi llișkisi
}

Kader IRAK, Ahmet Tarık EMINLER, Talat AYYILDIZ, Murat KESKIN, Selim Giray NAK, Murat KIYICI, Selim GÜREL, Macit GÜLTEN, Enver DOLAR

Uludağ University Faculty of Medicine, Department of Gastroenterology, Bursa, Turkey

\section{ABSTRACT}

Objective: To investigate the relationship of liver histopathology with the levels of noninvasive markers, namely hyaluronic acid (HA) type 4 collagen and procollagen 3 amino-terminal peptide (P3NP) used for the assessment of hepatic fibrosis in patients with chronic viral hepatitis.

Materials and Methods: The study included 80 patients, 56 with chronic hepatitis $B(\mathrm{CHB})$ and 24 with chronic hepatitis $\mathrm{C}(\mathrm{CHC})$ who presented to the outpatient clinic at Uludağ University Faculty of Medicine, Department of Gastroenterology, and underwent pretreatment liver biopsy between 2008 and 2010 . The patients were divided into 2 groups according to the degree of fibrosis: group 1 included patients with grade $\leq 3$ fibrosis (no fibrosis, mild or moderate), group 2 included patients with grade $\geq 4$ fibrosis (severe fibrosis). The association of hepatic fibrosis grade with HA, type 4 collagen, and P3NP was examined.

Results: Among the 65 patients in group 1 whose fibrosis grade was confirmed via liver biopsy, $47(72.3 \%)$ had HBV and 18 (27.7\%) had HCV, whereas 9 of $15(60 \%)$ in group 2 had HBV and 6 of $15(40 \%)$ had HCV. There was no significant difference in the non-invasive fibrosis markers between the groups ( $p>0.05$ ). In addition, there was not a significant difference in HA and P3NP levels between the CHB patients in groups 1 and 2 ( $p>0.05$ ), but the type 4 collagen level was significantly higher in

\section{ÖZET}

Amaç: Kronik viral hepatitli hastalarda karaciğerdeki fibrozunu değerlendirmede noninvaziv belirteçlerden olan hyaluronik asit (HA), tip 4 kollajen, prokollajen 3 aminoterminal peptit (P3NP) düzeyinin karaciğer histopatolojisi ile ilişkisi araştırımıştır.

Gereç ve Yöntemler: Çalışmaya 2008-2010 tarihleri arasında Uludağ Üniversitesi Tıp Fakültesi, Gastroenteroloji polikliniğine başvuran tedavi öncesi karaciğer biyopsisi yapılan 56 HBV'ye bağlı ve 24 HCV'ye bağlı hepatit olmak üzere toplam 80 hasta alındı. Fibroz derecesine göre evre $\leq 3$ olanlar grup 1 (fibroz yok, hafif veya orta), evre $\geq 4$ olanlar grup 2 (ileri fibroz) olarak kabul edildi. Hastaların serum fibroz derecesi ile HA, tip 4 kollajen, P3NP düzeyi ile olan ilişkisi incelendi.

Bulgular: Karaciğer biyopsilerinde fibroz derecesine göre grup 1 olan toplam 65 olgunun 47 'sinde $(\% 72,3)$ hepatit B virüsü, 18'inde $(\% 27,7)$ hepatit $C$ virüsü, grup 2 olan 15 olgunun 9'unda (\%60) hepatit B virüsü ve 6 'sında $(\% 40)$ hepatit $C$ virüsü mevcuttu. Tüm olgularda serum fibroz belirteçleri HA, tip 4 kollajen, P3NP düzeyleri ile grup 1 ve 2 arasında anlamlılık saptanmadı ( $p>0,05)$. Kronik hepatit B'de (KHB) HA, P3NP düzeyleri ile grup 1 ve 2 arasında anlamlılık saptanmadı $(p>0,05)$. Ancak grup 2 'de tip 4 kollajen düzeyleri anlamlı olarak yüksekti $(p<0,05)$. HA, tip 4 kollajen, P3NP düzeyleri Kronik hepatit $\mathrm{C}^{\prime}$ de $(\mathrm{KHC})$ fibroz grupları arasında anlamlı farklılık göstermedi $(p>0,05)$. 


\section{ABSTRACT}

the HBV patients in group $2(p<0.05)$. On the other hand, there were no significant differences in $\mathrm{HA}$, type 4 collagen, and P3NP levels, or fibrosis grade between the $\mathrm{HC}$ patients ( $p>0.05$ ).

Conclusion: The use of any marker or combination of markers examined in the present study is not a substitute for liver biopsy for assessing hepatic fibrosis. The fibrosis markers examined in the present study could be further examined in research on anti-fibrotic treatment. Future clinical investigations are needed for the evaluation of the value of these tests in diagnosis and monitoring. It should not be forgotten that the basic diagnostic approach is liver biopsy.

Key Words: Fibrosis, chronic viral hepatitis, non-invasive marker, liver biopsy

Conflict of interest: The authors reported no conflict of interest related to this article.
ÖZET

Sonuç: Çalışılan gösterge veya göstergeler kombinasyonu, karaciğer fibrozunun ortaya konmasında henüz karaciğer biyopsisinin yerini tutamamaktadır. Fibroz belirteçleri, gelecek yıllarda antifibrotik tedavi için yapılacak klinik çalışmalarda çok önemli roller üstlenebilirler. Bu testlerin tanı ve tedavi izlemindeki değerinin belirlenmesi için başka klinik çalışmalara gereksinim vardır ve temel tanı yönteminin karaciğer biyopsisi olduğu unutulmamalıdır.

Anahtar Kelimeler: Fibroz, kronik viral hepatit, non-invaziv belirteç, karaciğer biyopsi

Çıkar çatışması: Yazarlar bu makale ile ilgili olarak herhangi bir çıkar çatışması bildirmemişlerdir.

Department Outpatient Clinic between 2008 and 2010 and underwent pretreatment liver biopsy. Liver biopsy specimens were histopathologically evaluated using Ishak modification of the Knodell hepatic activity index and grade of fibrosis. Patients with grade $\leq 3$ fibrosis formed group 1 (mild fibrosis) and patients with grade $\geq 4$ fibrosis constituted group 2 (severe fibrosis). Blood specimens were obtained at the time of biopsy for measurement of HA, type 4 collagen, and P3NP levels. Following centrifugation, serum was separated and stored at $-80{ }^{\circ} \mathrm{C}$ until analysis. Analysis was performed via ELISA using the Human Hyaluronic Acid ELISA Kit (Cusabio Biotech, CO), the Procollagen 3 N-Peptide ELISA Kit (USCN Life Science), and the Collagen type 4 ELISA Kit (USCN Life Science).

\section{Statistical Analysis}

Statistical analysis was performed using SPSS v.13.0 for Windows (SPSS, Inc., Chicago, IL). Continuous variables were analyzed using the Shapiro-Wilk test for conformance to normal distribution. Inter-group comparison of variables with normal distribution was performed via the independent double samples t-test, whereas the Mann-Whitney U-test was used for variables not normally distributed. The Yates-corrected chi-square test and Fisher's exact chi-square test were used to compare categorical variables between the 2 groups. The level of statistical significance was set at $p<0.05$.

\section{Results}

Among the 80 participants, 50 (62.5\%) were male (mean age: $45.28 \pm 11.49$ years) and $30(37.5 \%)$ were female (mean age: $47.70 \pm 11.00$ years). In all, $56(70 \%)$ patients had $\mathrm{CHB}$ and 24 (30\%) had $\mathrm{CHC}$. Of the 65 patients in group 1, 47 (72.3\%) had $\mathrm{CHB}$ and $18(27.7 \%)$ had $\mathrm{CHC}$, versus $9(60 \%)$ of 15 with $\mathrm{CHB}$ and 6 (40\%) with $\mathrm{CHC}$ in group 2. There was not a significant difference between the serum fibrosis markers HA, type 4 collagen, or P3NP, according to the grade of fibrosis $(p>0.05)$ (Table 1$)$.
$(\mathrm{CHB})$ and 24 with chronic hepatitis $\mathrm{C}(\mathrm{CHC})$-who presented to Uludağ University Faculty of Medicine, Gastroenterology 
In addition, there was no significant difference in HA or P3NP levels between the CHB patients in groups 1 and 2 ( $p>0.05$ ), but type 4 collagen levels were significantly higher in the $\mathrm{CHB}$ patients in group 2 than in those in group $1(p<0.05)$ (Table 2).

In the patients with $\mathrm{CHC}$, there was not a significant difference in HA, type 4 collagen, or P3NP levels between the 2 groups (p>0.05) (Table 3).

\section{Discussion}

In many circumstances, patients with cirrhosis can be diagnosed only following the onset of overt symptoms, as hepatic fibrosis is usually clinically asymptomatic; therefore, early diagnosis of hepatic injury is crucial for diagnosis, treatment, and follow-up of any condition associated with chronic hepatic injury. In particular, treatment response is more effective in patients with chronic viral hepatitis when diagnosed during the early stages of disease (3).

Recent studies have focused on the development of biochemical and other non-invasive diagnostic methods (e.g. imaging techniques) that can replace histopathologic work-up, as well as the compatibility of such novel methods with histopathology. Bilirubin, aspartate transaminase (AST), alanine transaminase (ALT), alkaline phosphatase (ALP), gamma-glutamyltransferase (GGT), albumin and gamma globulin, platelet count, prothrombin time and activity, alpha-2-macroglubulin, haptoglobin, and apolipoprotein A-1 are routinely analyzed in serum and are indicative of the grade of fibrosis and hepatic reserve, but only roughly (4). More sensitive indices (Bonacini, Forns and APRI Index, ALT/AST ratio, Fibro test, Acti test, etc.) were developed based on the study of combinations of these methods $(5,6,7)$. Additionally, new laboratory tests have

\begin{tabular}{|c|c|c|c|}
\hline Chronic viral hepatitis & Group 1 & Group 2 & $\mathbf{p}$ \\
\hline Hyaluronic acid & $2.69 \pm 3.08$ & $2.20 \pm 1.99$ & 0.55 \\
\hline Type 4 collagen & $136 . \pm 33.74$ & $151.53 \pm 45.20$ & 0.15 \\
\hline Procollagen 3 & $1839.07 \pm 1246.26$ & $2377 . \pm 1084.79$ & 0.12 \\
\hline
\end{tabular}

Table 2. Serum levels of fibrosis markers in the chronic hepatitis B (CHB) patients, according to group (fibrosis grade)

\begin{tabular}{|l|l|l|l|}
\hline CHB & Group 1 & Group 2 & $\mathbf{p}$ \\
\hline Hyaluronic acid & $2.32 \pm 2.28$ & $2.85 \pm 2.21$ & 0.52 \\
\hline Type 4 collagen & $136.60 \pm 34.53$ & $173.55 \pm 44.57$ & 0.007 \\
\hline P3NP & $1751.95 \pm 1262.82$ & $2161.00 \pm 1248.78$ & 37 \\
\hline
\end{tabular}

P3NP: Procollagen 3 aminoterminal peptid, CHB: chronic hepatitis B

\begin{tabular}{|l|l|l|l|}
\hline \multicolumn{4}{|l|}{$\begin{array}{l}\text { Table 3. Serum levels of fibrosis markers in chronic hepatitits C } \\
\text { patients (CHC), according to group (fibrosis grade) }\end{array}$} \\
\hline CHC & Group 1 & Group 2 & p \\
\hline Hyaluronic acid & $3.73 \pm 4.60$ & $1.22 \pm 1.16$ & 0.31 \\
\hline Type 5 collagen & $137.05 \pm 32.58$ & $118.50 \pm 18.96$ & 0.14 \\
\hline P3NP & $2079.94 \pm 1202.83$ & $2701.83 \pm 717.62$ & 0.32 \\
\hline
\end{tabular}

P3NP: Procollagen 3 aminoterminal peptid, CHB: chronic hepatitis B recently become commercially available in the form of test kits, following identification of some novel markers that could be used to assess fibrosis in tissue (e.g. laminin, HA (hyaluronic acid), YKL-40 (condrex), TIMP-1 (tissue inhibitor of matrix metalloproteinase-1), TIMP-2, P3NP (procollagen 3 amino-terminal peptide), MMP 1,2,3 (matrix metalloproteinase) and 9, PDGF-BB (platelet-derived growth factor-BB), TGF- $\beta 1$ (transforming growth factor- $\beta 1$ ), type 4 collagen, fibronectin, and n-epsilon-(carboxymethyl) lysine) (8).

Development of fibrosis is associated with a highly complex mechanism and is characterized by matrix deposition secondary to increased synthesis and decreased degradation of extracellular matrix in tissue due to the actions of various cytokines that are released during inflammation. Serum and hepatic tissue procollagen 1 and 3 , type 1 and 4 collagen, YKL-40, laminin, and HA levels are indicative of matrix deposition, whereas MMP-2, MMP9, TIMP-1, and TIMP-2 are also markers of matrix degradation and TGF- $\beta 1$, TGF-1, and PDGF test results are indicative of cytokines associated with fibrogenesis (9).

Hyaluronic acid, which is synthesized in hepatic stellate cells and broken down in hepatic sinusoidal cells, is a component of extracellular matrix. In healthy liver, its concentration is low where in fibrotic liver is high. (1).

Studies have shown that the HA level is associated with the severity of fibrosis in patients with $\mathrm{CHC}(10,11,12)$ and a study from the US that included 486 patients with $\mathrm{CHC}$ from 41 centers concluded that the HA level increases progressively along with the grade of fibrosis (13). A study conducted in Turkey that included 40 patients with $\mathrm{CHB}$ and $\mathrm{CHC}$ reported that although the HA level was directly proportional to the level of fibrosis in patients with $\mathrm{CHB}$, the difference was only significant in patients with $\mathrm{CHC}$ (1). Moreover, a decrease in the HA level was observed in patients with hepatitis $C$ who exhibited biochemical response to interferon monotherapy (14). A study from Egypt that compared hepatic histopathology, and serum fibrosis markers HA and YKL-40 in 220 $\mathrm{CHC}$ patients (91\% had genotype-4 HCV infection) reported that although HA and YKL-40 were useful for assessment of disease activity, they were not indicative of fibrosis (15).

In our study, there was no difference in HA levels between group 1 (low fibrosis) and 2 (advanced fibrosis) chronic viral hepatitis patients ( $p>0.001$ ). In summary, HA serum levels can be used to evaluate liver damage instead of being the potential index for liver fibrosis.

In liver fibrosis, one of the most studied indicators is P3NP. Its level is high in acute and chronic liver patients. Several studies reported that the serum P3NP level was indicative of histological stage of hepatic fibrosis in patients with alcoholic liver disease, viral hepatitis, and primary biliary cirrhosis $(16,17,18)$. P3NP, laminin, and $7 \mathrm{~S}$ collagen levels were correlated with grade of hepatic fibrosis in patients with chronic viral hepatitis (19), however, other studies reported that the P3NP level was correlated with activity scores rather than fibrosis grade $(20,21,22)$. In contrast, other studies observed a decrease or normalization of the P3NP level in patients with hepatitis $\mathrm{C}$ infection who responded to interferon therapy $(23,24)$; similar findings were reported for HA and TIMP-1 (25).

P3NP levels are highly associated with the fibrotic stage of alcoholic liver disease. P3NP level is getting higher during acute hepatic attacks in cirrhosis patients, which supports the role of 
ethanol metabolites in fibrogenesis (17). In our study, there was no difference in P3NP levels between low and advanced fibrosis groups.

Based on observations that type 4 collagen was more sensitive than laminin, HA, and P3NP for the assessment of fibrosis in patients with chronic hepatitis, several studies on protein yielded inconsistent findings (26). Type 4 collagen can be located in blood and lymph vessels and also in basal membrane of bile ducts, around nerve cells axons and perisinusoidal cleavage. Although type 4 collagen was observed to be more informative than platelet count in patients with $\mathrm{CHC}$, it was associated with biochemical and histological improvement in response to interferon therapy $(27,28)$, however, it was observed that type 4 collagen was not correlated with the stage of fibrosis in patients with HBV infection (21). Among the present study's patients with $\mathrm{CHB}$, the serum type 4 collagen level was significantly higher in group 2 (the severe fibrosis group) ( $p=0.007$ ).

Among serological tests, currently, the most useful markers are HA, type 4 collagen, P3NP, laminin, and YKL-40, although some studies have reported contrasting results, however, no marker has been proven to be superior, and as such, the best approach would be combined use of those tests. A meta-analysis of 14 studies on hepatitis $\mathrm{C}$ reported that multiple test parameters had a wide range of sensitivity, ranging from $17 \%$ to $80 \%$ (mean: $40 \%$ ), for diagnosing advanced-stage fibrosis (29).

In conclusion, these tests can be used for non-invasive monitoring of disease activity, and assessment of post-treatment fibrosis and activity decrease in patients with chronic viral hepatitis. Fibrosis marker findings of this study could be used to contribute future clinical studies that should be conducted in an effort to develop a specific anti-fibrotic treatment. Nonetheless, clinicians must be aware that these tests are currently of limited value and that the gold standard for diagnosis remains liver biopsy. Larger scale prospective studies are needed in order to further clarify this issue.

\section{References}

1. Arhan M, Köksal AŞ, Yüksel $O, A$ Akdoğan M. Significance of Serum Hyaluronic Acid Level in Assessment of Hepatic Fibrosis. Türkiye Klinikleri J Med Sci 2007;27(1):21-6.

2. Curry MP Afdhal NH. Non-invasive markers of hepatic fibrosis. Rose BD (Editor). Wellesley (MA): Up TO date [CD ROM];2000.

3. Aydın Z, Demir K, Ökten A, Kaymakoğlu S, Salmayenli N, Özdil S, Karaca Ç, Danalıoğlu A, Koroğlu G, Beşışık F, Boztaş G, Mungan Z, Çevikbaş U, Çakaloğlu Y. Assessment of noninvasive tests as marker of fibrosis in chronic viral hepatitis cases. Istanbul Üniversitesi Tıp Fakültesi Dergisi. 2003; 66:171177.

4. Bataller R, Brenner DA. Liver fibrosis. J Clin Invest. 2005: 115:209-218.

5. Hui AY, Chan HL, Wong WW, Liew CT, Chim AM, Chan FK, Sung JJ. Identification of chronic hepatitis B patients without significant liver fibrosis by a simple noninvasive predictive model. Am J Gastroenterol. 2005; 100:616-623.

6. Rockey DC, Bissell DM. Noninvasive measures of liver fibrosis. Hepatology. 2006; 43(Suppl 1):113-120.

7. Poynard $T$, Imbert-Bismut $F$, Munteanu $M$, Messous $D$, Myers RP, Thabut D, Ratziu V, Mercadier A, Benhamou Y, Hainque B. Overview of the diagnostic value of biochemical markers of liver fibrosis (FibroTest, HCV FibroSure) and necrosis (ActiTest) in patients with chronic hepatitis C. Comp Hepatol. 2004; 3:8.
8. Kawada N. Molecular mechanism of stellate cell activation and therapeutic strategy for liver fibrosis. Comp Hepatol. 2004; 3(Suppl 1):3.

9. Zeremski M, Talal AH. Noninvasive markers of hepatic fibrosis: are they ready for prime time in the management of HIV/HCV co-infected patients? J Hepatol. 2005; 43:2-5.

10. Halfon $P$, Bourlière $M$, Pénaranda $G$, Deydier R, Renou $C$, Botta-Fridlund D, Tran A, Portal I, Allemand I, Rosenthal-Allieri $A$, Ouzan D. Accuracy of hyaluronic acid level for predicting liver fibrosis stages in patients with hepatitis $\mathrm{C}$ virus. Comp Hepatol. 2005; 4:6.

11. Wong VS, Hughes V, Trull A, Wight DG, Petrik J, Alexander GJ. Serum hyaluronic acid is a useful marker of liver fibrosis in chronic hepatitis C virus infection. J Viral Hepat. 1998; 5:187192.

12. Fontana RJ, Goodman ZD, Dienstag JL, Bonkovsky HL, Naishadham D, Sterling RK, Su GL, Ghosh M, Wright EC: HALT-C Trial Group. Relationship of serum fibrosis markers with liver fibrosis stage and collagen content in patients with advanced chronic hepatitis C. Hepatology. 2008; 47:789-798.

13. McHutchison JG, Blatt LM, de Medina M, Craig JR, Conrad A, Schiff ER, Tong MJ. Measurement of serum hyaluronic acid in patients with chronic hepatitis $\mathrm{C}$ and its relationship to liver histology. Consensus Interferon Study Group. J Gastroenterol and Hepatol. 2000; 15:945-951.

14. Guéchot J, Serfaty L, Bonnand AM, Chazouillères O, Poupon $R E$, Poupon R. Prognostic value of serum hyaluronan in patients with compansated HCV cirrhosis. J Hepatol. 2000; 32:447-452.

15. Esmat G, Metwally M, Zalata KR, Gadalla S, Abdel-Hamid M, Abouzied A, Shaheen AA, El-Raziky M,Khatab H, El-Kafrawy S, Mikhail N, Magder LS, Afdhal NH, Strickland GT. Evaluation of serum biomarkers of fibrosis and injury in Egyptian patients with chronic hepatitis C. J Hepatol. 2007; 46:620-627.

16. Montalto G, Soresi M, Aragona F, Tripi S, Carroccio A, Anastasi G, Magliarisi C, Barresi E, Notarbartolo A. [Procollagen III and laminin in chronic viral hepatopathies]. Presse Med. 1996; 25:59-62.

17. Teare JP, Sherman D, Greenfield SM, Simpson J, Bray G, Catterall AP, Murray-Lyon IM, Peters TJ,Williams R, Thompson RP. Comparison of serum procollagen III peptide concentrations and PGA index for assesment of hepatic fibrosis. Lancet. 1993; 342:895-898.

18. Trinchet JC, Hartmann DJ, Pateron D, Laarif M, Callard P, Ville G, Beaugrand M. Serum type I collagen and N-terminal peptide of type III procollagen in chronic hepatitis. Relationship to liver histology and conventional liver tests. J Hepatol. 1991; 12:139144.

19. Misaki M, Shima T, Yano $Y$, Sumita $Y$, Kano $U$, Murata $T$, Watanabe S, Suzuki S. Basement membrane-related and type III procollagen-related antigens in serum of patients with chronic viral liver disease. Clin Chem. 1990; 36:522-524.

20. McCullough AJ, Stassen WN, Wiesner RH, Czaja AJ. Serial determinations of the amino-terminal peptide of type III procollagen in severe chronic active hepatitis. J Lab Clin Med. 1987; 109:55-61.

21. Chen YP, Feng XR, Dai L, Zhang $L$, Hou JL. Non-invasive diagnostic screening of hepatic fibrosis in patients with chronic hepatitis B. Chin Med J (Engl). 2004; 117:1109-1112.

22. Giannini E, Caglieris S, Ceppa P, Risso D, Lantieri PB, Testa R. Serum pro-collagen III peptide levels are related to lobular necrosis in untreated patients with chronic hepatitis C. Eur J Gastroenterol Hepatol. 2001;13:137-141.

23. Gallorini A, Plebani M, Pontisso P, Chemello L, Masiero $M$, Mantovani G, Alberti A. Serum markers of hepatic fibrogenesis in chronic hepatitis type $\mathrm{C}$ treated with alfa-2A interferon. Liver. $1994 ; 14: 257-264$. 
24. Yagura M, Murai S, Kojima H, Tokita H, Kamitsukasa H, Harada $\mathrm{H}$. Changes of liver fibrosis in chronic hepatitis $\mathrm{C}$ patients with no response to interferon-alpha therapy: including quantitative assessment by a morphometric method. J Gastroenterol. 2000; 35:105-111.

25. Trocme C, Leroy $V_{\text {, Sturm N }}$, Hilleret MN, Bottari S, Morel F, Zarski JP. Longitudinal evaluation of a fibrosis index combining MMP-1 and PIIINP compared with MMP-9, TIMP-1 and hyaluronic acid in patients with chronic hepatitis $C$ treated by interferon-alpha and ribavirin. J Viral Hepat. 2006; 13:643-651.

26. Xie, J, Ou Yang K, Su T. [Serum type IV collagen and laminin in patients with chronic hepatitis and its clinical significance]. Hunan Yi Ke Da Xue Xue Bao. 1998; 23:93-96.
27. Murawaki Y, Koda M, Okamoto K, et al. Diagnostic value of serum type IV collagen test in comparison with platelet count for predicting the fibrotic stage in patients with chronic hepatitis C. J Gastroenterol Hepatol 2001;16:777-83.

28. Yabu K, Kiyosawa K, Mori H, et al. Serum collagen type IV for the assesment of fibrosis and resistance to interferon therapy in chronic hepatitis C. Scand J Gastroenterol 1994; 29:474-80

29. Parkes J, Guha IN, Roderick P, Rosenberg W. Performance of serum marker panels for liver fibrosis in chronic hepatitis C. J Hepatol 2006;44:462-74. 